\title{
Critical realism and its prospects for African development research and policy
}

\author{
James M. Njihia \\ Department of Management Science
}

University of Nairobi

muranga.njihia@gmail.com OR njihia@uonbi.ac.ke

Thought and Practice: A Journal of the Philosophical Association of Kenya (PAK)

New Series, Vol.3 No.1, June 2011, pp.61-85

thoughtandpractice@gmail.com

http://ajol.info/index.php/tp/index

\begin{abstract}
This paper outlines critical realism, a relatively new philosophy of science, in an attempt to increase awareness of it amongst African researchers. The paper argues that this school of thought has important implications for framing social science research and development policy in developing countries. Critical realism is a radical critique of the Western philosophy, especially positivism that is closely associated with rational choice theory and Western modernity. It has four discernible progressive phases, each of which is a complete philosophical system. A discussion of its relevance to African scholars follows, centered on the fact that critical realism gives primacy to the human values of freedom and emancipation rather than to material concerns which are central to Western modernity. Recent publications have challenged contemporary African philosophy to be more responsive to popular aspirations for socio-
\end{abstract}


economic development, instead of dwelling excessively on long running debates amongst different schools of philosophy. Critical realism is presented as worthy of further investigation by scholars in Africa that seek new ways forward, and relevance in a rapidly changing world. Development research and policy is used to illustrate its potential. It is found that a critical realist approach may lead to meeting of some important precedents necessary for any meaningful development to occur in Africa.

Key Words. Critical realism, economic development, development policy, social science research.

\section{Introduction: development, modernization and philosophy}

The practice of economic development that is a chief concern of most African policy makers is informed by the applied sciences and their underlying philosophical paradigms. The record shows that African societies have sought to advance economically and socially following theories of economic development such as modernization, dependency, and Marxism. Modernization has been the preferred approach by international development institutions that conceive development as a linear progress. It requires the application of the scientific method in development planning, and that often requires mathematical techniques in the social sciences to optimize resource allocation in an environment of scarcity. Thus a positivist paradigm that calls for objectivity and deductive reasoning towards logical conclusions has been the default philosophy in the practice of development. It shall be argued that this leads to an impoverished conception of development, and only serves to keep African countries within the Western sphere of influence. It ignores the human values of freedom and emancipation that would be central to any valid conception of development in Africa.

Critical realism is an approach that merits attention from African philosophers and critical social science researchers. Its provocative approach to established schools of thought in Western philosophy has been controversial, and has enriched philosophical debate, particularly in Europe where it is better known. One problem has been its inaccessibility to a broader audience owing to the difficult writing style of British philosopher Roy Bhaskar, its founder and principal writer. 
The British version of critical realism discussed here is different from that founded in America by the same name associated in early $20^{\text {th }}$ Century with Roy Wood Sellars, George Santayana and Arthur Lovejoy (Pedro 2009), or that used in theological studies in North America by Bernard Lornegan. ${ }^{1}$ It may however be directly linked to developments in critical theory from the Frankfurt School, which was a reaction against the excesses of logical positivists of the Vienna Circle. Roy Bhaskar's work may therefore be seen as a logical critical extension of the Frankfurt School, but with a radical reformulation of foundational concepts in philosophy.

Bhaskar's critical realism is a complex set of progressively abstract constructs such that utilizing them without a full grasp of its scope vitiates its critical intent, and may collapse into formulaic prescriptions that reflect the traditional positivist - interpretive dichotomy in Western philosophy. In this paper I outline the principal arguments of critical realism with two aims, namely, to increase awareness amongst African social science researchers, and to enrich debate amongst researchers in Africa beyond 'perverse and unnecessary dialogues' (Vest 2009), towards a dialogue that engages constructively with the theory and practice of development. I shall first introduce the philosophy of critical realism, and then discuss its prospects for African scholarship in relation to the practice of development.

\section{Critical realism and philosophy of science}

Positivism is the dominant philosophical paradigm in the social sciences in comparison to others such as interpretivism, critical theory and critical realism (Chen and Hirschheim 2004). Positivism conceives of reality as knowable through objective methods of observation and logical deduction. For interpretivism on the other hand, reality is subjective and its conception is dependent on the human observer and their interpretation of the meaning of such observations. Between these two extremes are several schools of thought such as critical theory, social constructivism, and critical realism, each of them with a different emphasis. Critical realism is often presented as a meta-critique of positivism as an ideology (Bhaskar 1986, Chapter 3; Collier 1994, 101). However, as will be seen below, it is also a critique of the other paradigms because

${ }^{1}$ METHOD: Journal of Lonergan Studies furthers Bernard Lonergan's critical realism and is published twice yearly by The Lonergan Institute at Boston College. 
they share the same premises as positivism. Schumacher's (1974) critique of orthodox economics which is positivist in the best selling Small Is Beautiful also anticipated themes in critical realism. For example, Schumacher sought a metaphysics that gives inner clarity to people's basic convictions despite limited knowledge of facts and theories. In the process he anticipated many critical realist notions such as depth ontology and epistemological relativism. He rejects the assumptions of system closure and reductionism as concerned only with convergent problems, while divergent problems are the "real stuff of life" (Schumacher 1974, 81). He deplores the preclusion of ethical issues in economic analysis by a denial that society and humans have different levels of being, similar to critical realist notions of stratified reality and emergence. Other anticipatory contributions were the Marxian/historical and structural reformulation of political economy by Ferdinand Braudel and the Annalles school historians (Clark 1990), Immanuel Wallerstein (1991) and Samir Amin (Ruccio and Simon, 1992). These are usually classified as heterodox economists, and are marginal to mainstream economics. Ackroyd and Fleetwood (2000) retrospectively ascribe as being in tune with critical realism to names such as Marx, Weber, Durkheim, Commons, Veblen, Mannheim, Mills, Karl Polanyi, Bourdieu and Chomsky; they also state that institutional theory anticipated realism. Critical realism therefore challenges orthodoxy in social science with metaphysical arguments that bring together many previous lines of enquiry.

Critical realism arose from Roy Bhaskar's attempt to explain underdevelopment within orthodox economics for his doctoral studies (Norris 1999). He found that orthodox economics' commitment to an empiricist epistemology forbade discourse about ontology that was important to his enquiry. Subsequent study under leading realist, Rom Harre led Bhaskar to a new philosophy for science from a reconsideration of seminal works by Hume and Kant (Bhaskar 1978). Critical realism is by now a broad internally consistent philosophical system that attempts the transcendence of various dualisms such as objective-subjective, and positivisminterpretivism, divisions in philosophy of science that most physical and social scientists take for 
granted. It has evolved over four stages or moments, each corresponding to a Bhaskar text as outlined in the following subsections (book title in parentheses). ${ }^{2}$

Note that critical realist writings, especially Bhaskar, have been classified as difficult, and introduce many neologisms and new concepts, while existing concepts may get a whole new interpretation (Mutch 2002). It is often easier to first read other critical realist writers to grasp Bhaskar's works; this has hindered their wider dissemination. At the same time, Bhaskar's fairly rapid conceptual innovations in moving from one stage to the other would be a challenge for anyone to keep up with.

\section{Transcendental Realism (A Realist Theory of Science)}

Transcendental realism was Bhaskar's first and most important philosophical innovation. It is a reformulation of philosophy for the experimental sciences where Bhaskar sets out the principal critical realist arguments for depth realism in social reality, the transitive and intransitive dimensions, and against what he terms the epistemic fallacy and anthropocentric bias of Western philosophy (Bhaskar 1978). Knowledge is obtained from answering the transcendental question: "What must the world be like for science to be possible?" The answer can be established by way of a philosophical argument about ontology. With this approach, philosophy thus regains the critical role of investigating how scientific knowledge is actually generated, in contrast to empiricist based approaches that address only the justifiability of knowledge claims. The latter approach is in the domain of epistemology, which had been the dominant concern for philosophy of science especially since Descartes for whom thinking was the path to knowledge, up to and until Martin Heidegger's Being and Time, where through the concept of dasein or 'being in the world', European philosophers rediscovered ontology and existence philosophy. Bhaskar too gives a more important role to ontology rather than to epistemology in philosophy of science. The main concepts of Transcendental Realism are explained in the following sections.

\footnotetext{
${ }^{2}$ The summary of the critical realist movement in the next sections draws primarily from Dean, Joseph and Norrie (2005), in addition to each of Bhaskar's texts, whose titles are stated in parentheses for each subheading, as well as other cited sources.
} 


\section{Transitive and intransitive dimensions of knowledge}

Transcendental realism distinguishes between two realms of scientific knowledge termed the transitive and intransitive dimensions. The intransitive dimension comprises things that do not depend on human activity; the transitive dimension is of things that are related or in some way affected by human beings. This distinguishes our knowledge which is changeable, from the objects of such knowledge, said to be real and that do not depend in any way on our knowing them. Hence transcendental realism admits ontological realism, that there exists a reality apart from human knowledge or activity. However, we can have only partial knowledge that is subject to revision of such a reality, which only allows for an epistemological relativism, a relativism constrained by the possibility of attaining true knowledge of real objects.

\section{The Epistemic fallacy and anthropocentric bias}

To sustain the distinctions of knowledge above, Bhaskar revisited founding texts of Western epistemology. Kant's Copernican revolution was a synthesis of Cartesian rationalism and Humean empiricism to set out the synthetic a priori conditions for knowledge. Crucially, it also resulted in what Quine (1951) terms the Kantian cleavage of objective and subjective realms of knowledge. According to Schumacher (1974), Kant's separation of objective from subjective, together with Newton's discoveries and the scientific method, laid the foundation for Western intellectual and industrial progress, though with a 'severely deformed metaphysics' for human society as a whole to thrive. Kant's resolution of Hume's empirically founded skepticism and Descartes' rationalism resulted in transcendental idealism that continued the neglect of ontology in what Bhaskar terms the epistemic fallacy (Bhaskar 1978). This is "the idea that one can reduce or analyze knowledge in terms of being" (Norris 1999). The epistemic fallacy "screens the role of theory, on the one hand, and of knowable things, on the other, in the constitution of facts and experience" (Bhaskar 1986, 296). In this manner, reified facts effectively rationalize theoretical status quo in normal science.

Kant also placed man at the center of knowing, providing modernity's anthropocentric bias, so that things are either scientific or voluntaristic, which stems from empiricism that "the world is what men can experience" (Bhaskar 1978, 58). This has the ideological consequence from the scientific practice point of view, that "whatever men currently experience is unquestionably the world" (Bhaskar 1978, 58). Collectively the epistemic fallacy and anthropocentric bias lead to 
what Bhaskar $(1978,61)$ terms 'idols' - "false conceptions which cause men to see, in philosophy, everything in relation to themselves and their present knowledge".

While Kant was concerned with how we 'know that we know', Bhaskar concentrated on what the 'world had to be like' for us to know it scientifically. His ontological rather than epistemological approach therefore opened the way for an alternative philosophical ontology. Critical realism holds that both positivism and interpretivism commit the epistemic fallacy, which allows them to co-exist in an apparent complementary contradiction, since none is actually concerned with ontology per se. Bhaskar also rejects the implicit acceptance of the Humean constant conjunction of events in both philosophical traditions in causal explanation. Instead he posits a real stratified ontology with generative mechanisms that give rise to events and empirical observations (Collier 1994, 42-50). For critical realists, what really matters are the mechanisms: the rest are merely observable epiphenomena that ought not to be confused for, nor equated to, the underlying reality.

\section{Depth realism, mechanisms, and social reality}

From the distinction in the two dimensions of knowledge, it follows that social reality is divided into domains with varying degrees of access as shown in Table 1. Empiricism only recognizes the empirical which is directly observable; Bhaskar adds the actual, and the real. The domain of the actual is composed of events and experiences and is the result of a multiplicity of underlying real mechanisms. The domain of the real is composed of mechanisms that are not observable and can only be inferred from events and empirical observations. Not all events are experienced, and not all mechanisms are actualized, which implies that we can only have limited knowledge of what underlies observations, and even less on what underlies events.

Table 1 Domains in Social Reality

\begin{tabular}{|l|l|l|l|}
\hline \multirow{2}{*}{} & \multicolumn{2}{|l|}{ Domains } \\
\cline { 2 - 4 } & Real & Actual & Empirical \\
\hline Mechanism & $\mathrm{X}$ & & \\
\hline
\end{tabular}




\begin{tabular}{|l|l|l|l|}
\hline Events & $\mathrm{X}$ & $\mathrm{X}$ & \\
\cline { 1 - 3 } Experiences & $\mathrm{X}$ & $\mathrm{X}$ & $\mathrm{X}$ \\
\hline
\end{tabular}

Sou

rce:

Bha

ska

r $(1978,13)$

The idea of mechanisms allows critical realism to ascribe causality to something beyond Humean empiricism that rejects anything not experienced from knowledge. When events occur, it is presumed that some structure has generated powers that give rise to the event; the structure(s) is said to constitute a generative mechanism for the event in critical realist terminology.

Since experiences and events are in the domain of the empirical or the actual, analysis involves the critical exploration of underlying mechanisms in the domain of the real that would give rise to the events and observations. One can always go deeper to reveal different explanatory levels or strata in Bhaskar's terminology; stratification is at the level of the real in mechanisms, not in things or events (Bhaskar 1978; Collier 1994). For example, a biological entity is unintelligible without chemistry, and at a lower level, physics; yet it is not reducible to chemistry, nor is chemistry reducible to physics. Depth realism and the idea of mechanisms call for a reevaluation of what we call science and its practice.

\section{Emergence and explanation in open systems}

Higher levels in the stratified reality are said to be emergent from lower levels and are not reducible to them. The critical realist account of social reality is as an open system, unlike empiricism that requires closure for scientific explanation. Scientific experiments are necessary as artificial closures for prediction to be possible. However, in open systems, there is an asymmetric relationship between explanation and prediction, since there is no guarantee that the conditions under which the explanation was obtained will hold. Scientific analysis is valuable because it has the potential to uncover deeper explanatory mechanisms in the stratified account of nature in progressive explanations. In this respect therefore, critical realism provides the methodological and philosophical framework for scientific realism (Boyd 2002), which holds that well established scientific knowledge is of phenomena that are largely theory independent. 
Such phenomena would correspond to mechanisms in critical realism. Researchers frequently develop models as scientific explanations of phenomena. From a transcendental realist point of view, such models are "simply a word[s] for a hypothesized generative mechanism" (Collier 1994, 68), thus allowing for further research and refinement. Scientific explanation now takes the form of historical causal analysis in four steps:

1. Resolution of a complex event into its components (causal analysis).

2. Redescription of component causes.

3. Retrodiction to possible (antecedent) causes of the components via independently validated normic ${ }^{3}$ statements.

4. Elimination of alternative possible causes of components.

(Bhaskar 1998, 129)

Collier (1994) explains that this is a variation on normal scientific practice which begins with a description and ends with the empirically-controlled identification of a causal mechanism at work, or 'answer', indicating experimental closure. The new approach suggests that we always begin with an existing body of concepts and constructs that are then revised continuously. As a philosophy, transcendental realism accepts ontological realism and epistemological relativism with a new approach to explanation in open systems. The term critical realism (CR) is the conjunction of transcendental realism $(\mathrm{TR})$ and critical naturalism $(\mathrm{CN})$.

\section{Critical Naturalism (The Possibility of Naturalism)}

Critical naturalism was the second moment as the logical extension of transcendental realism into the social sciences to answer the question "What properties do societies possess that might make them possible objects of knowledge for us?" (Bhaskar 1998, 25). It is identified with postpositivism in philosophy of science. The principal argument for naturalism turns on recognizing reasons as causes in scientific explanation of intentional and causally efficacious human actions. Secondly, society is not reducible to people; instead, social forms such as cultural norms, customs and family systems pre-exist people, and can therefore be studied as autonomous

\footnotetext{
${ }^{3}$ Normic laws have the form "if A, then normally B." in Schurz (2001, 476-477).
} 
entities with causal powers. Human agency is therefore both enabled and constrained by objective social realities. So the manner in which humans form beliefs and the nature of such beliefs becomes a legitimate subject for scientific analysis, and the entry point for explanatory critiques and the possibility of emancipatory action. Emancipation is conceived in a broad sense. The need for emancipation arises from the possible existence of false beliefs of any nature that constrain human agency. A person may have been raised believing that they are biologically or socially inferior due to the color of their skin. With time they notice that they do not seem to have any fundamental defect, thus exposing the falsity of the belief on the evidence of a successful life. They will from that point onwards start to live more fully, and even be moved to help others similarly trapped by the false belief.

At a societal level, false beliefs manifest as ideologies, and their exposure could lead to concrete actions to attain social justice or political freedoms. Such beliefs are considered social objects in critical naturalism. Ideology can be demonstrated by showing beliefs to be false or superficial, and, "in addition, being able to give an account of the reasons why the false or superficial beliefs are held..." (Bhaskar 1998, 53). Falsehoods may be inserted in gaps between the real, the actual, and the empirical. Of particular significance for critical realists are systemically generated and engendered ideologies in capitalist societies. By delineating the origin and falsity of such beliefs through explanatory critiques, it is hoped that people will increase their powers to distinguish between necessary and unnecessary constraints for emancipatory action.

\section{SOCIETY}

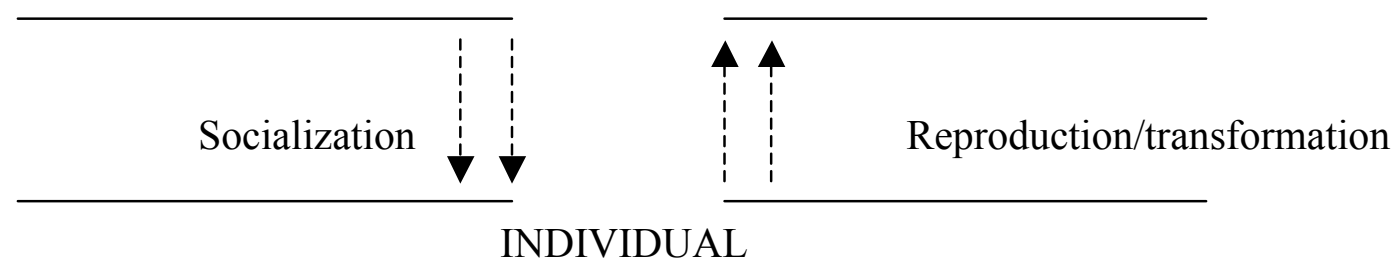

Figure 1 Transformational Model of Social Activity

Source: Archer (1995:155)

Bhaskar developed the Transformational Model of Social Activity (TMSA) shown in Figure 1 as a preliminary dialectical model for the interplay between subjective human agency and objective 
social reality (Archer 1995; Bhaskar 1998). The TMSA extends the concept of emergence to social systems to explain complex phenomena in a non-reductive manner whereby individuals and society are mutually constitutive. Individuals are socialized into society, while they in turn reproduce and transform it. ${ }^{4}$ Linear prediction models as used in orthodox development planning would not suffice with an emergent model of dynamic social reality, and this raises important questions for development planners and policy makers.

The next stage was full dialecticization for a better account of social reality and to resolve some philosophical problems raised by the division between individual and society, and the apparent absence of historicity.

\section{The Dialectical Turn (Dialectic: the Pulse of Freedom)}

Critical realism raised many questions and had conceptual problems such as the possible existence of two ontologies, one on the transitive dimension and one on the intransitive dimension in its account of the ontology of social structures (Cruickshank 2004). ${ }^{5}$ Dialectical Critical Realism (DCR) is a deepening and elaboration of critical realism through complete dialecticization. DCR opposes 'pure presence' or ontological monovalence (similar to Derrida's logocentricism) to stress the ontological primacy of absence; the concept of dialectic becomes the 'absenting of absence', as will be elaborated below. The categorical inclusion of absence resolves many binary oppositional concepts in philosophy of science and social theory in a richer dialectical schema.

DCR is founded on moral realism and ethical naturalism, which extends beyond critical naturalism to a spatio-temporal, moral, and truth (alethic) realism. Without these categories being would be de-totalized; Bhaskar considers moral irrealism as devaluing social life (Bhaskar 1993). The system is summarized as the MELD ( $1^{\text {st }}$ Moment, $2^{\text {nd }}$ Edge, $3^{\text {rd }}$ Level, and $4^{\text {th }}$ Dimension) schema of dialectical critical realism, in which Bhaskar sets out four degrees of critical realism with progressive dialecticization. Each degree has different categories (shown in italics below) that differ markedly from the Hegelian dialectic (thesis-antithesis-synthesis):

\footnotetext{
4 This is similar to Anthony Giddens' Structuration Theory (Giddens 1979), but again critical realism's TMSA differs in the conception of the nature of reality as with other critical and interpretive or constructivist social theories.

5 These are discussed further ahead under the section 'Some objections to critical realism'.
} 
1M (First Moment) - Non-identity. This is similar to the earlier ontology of structure, stratification, emergence and change that generate apparent contradictions in social reality. $1 \mathrm{M}$ relates to material interactions with nature. $1 \mathrm{M}$ is dialecticized in $2 \mathrm{E}$.

2E (Second Edge) - Negativity. Emphasizes absence and negativity. Change is conceptualized as absentings, and human agency as embodied intentional causal absenting. 2E relates to inter-personal relations.

3L (Third Level) - Dialectical totality. This logically follows from 2E where phenomena are seen as part of a total whole. Progressive absentings are remedied by resorting to a wider totality when they can be perceived as part of a whole; $3 \mathrm{~L}$ relates to social relations.

4D (Fourth Dimension) - Dialectical praxis. At 3L we attain theoretical understanding, moving on to $4 \mathrm{D}$, where transformative praxis is attained, which relates to intra-subjectivity.

The MELD schema generalizes critical realism for human beings in history under the universalizing theme of the pursuit of human freedom through successive absenting. The 'pulse of freedom' which forms part of the title of the key text - Dialectic: the Pulse of Freedom - is said to beat in every human, and eventually becomes a movement to absent unwanted constraints.

A Social Cube of the '4-planar social being' in four dialectically dependent planes now replaces the Transformational Model of Social Activity (TMSA) in modeling emergence in social reality. These are:

(a) Material transactions with nature;

(b) interpersonal relations;

(c) Social relations;

(d) Intra-subjectivity.

The Social Cube therefore avoids the ontological hiatus between individual and society evident in the TMSA, though it still retains the idea that individuals can still overcome even strongly disabling social structures to attain human freedom. Dialectical critical realism is therefore very 
different from Critical Naturalism, but preserves it within a more generalized schema. The next and final development is much more radical and generated much contention amongst both proponents and opponents of the developing philosophical system (Patomäki 2002).

\section{The Spiritual Turn (East to West: the Odyssey of a Soul)}

Bhaskar (2000) now makes a radical departure from his earlier 'mundane' concerns to a quasireligious philosophy of meta-reality termed Transcendental Dialectical Critical Realism (TDCR). Following the idea of a stratified reality, he posits a human reality outside of ordinary experience, beyond society and even history. It is an attempt at transcending ordinary reality. Our direct empirical world of embodied human relations is assumed to be dualistic, since it is an egocentric 'I', disconnected from our true human essence, which is connected as it were, to other humans, God, the world. Earlier expositions of social ontology would therefore be demi-real. Instead of freeing humans from constraints as in the case of critical naturalism and dialectical critical realism, the aim for true human existence becomes self-realization and God-realization, ultimately giving rise to human flourishing in a eudaimonistic society.

Clearly this last moment is very contentious, because it goes beyond the traditional boundaries of science into religion and spirituality. Its quasi-religious premises and concepts are drawn from Eastern (Oriental) and New Age religions, and are difficult to accept for most people, with many wondering whether this was the end of Bhaskar's philosophical system (Dean et. al. 2005; Patomäki 2002). However, TDCR concepts may be useful as a meta-philosophical system within which to frame higher level issues of morality and spirituality.

I agree with Porpora (2005) that this new philosophy of meta-reality is not contiguous with earlier developments: it more properly reflects a spiritual turn in Bhaskar himself rather than in critical realism as a philosophical system. For this reason, one can comfortably accept earlier developments without having to also take the spiritual turn. Not surprisingly, selective appropriation of the movement is common amongst researchers associated with critical realism. Not all accept all the four moments, and there is a lively ongoing debate through workshops, journals, conferences, and on the internet. Some are uncomfortable with the universalizing Kantian and Habermasian elements in the last two moments, with arguments for an inchoate ethic similar to post-structuralism. Others feel that freedom ought not to be a universal, but rather rationed amongst other priorities. In the next sections I draw attention to some common 
objections to critical realism, and some philosophical and methodological limitations that a social science researcher ought to keep in mind.

\section{Some objections to critical realism}

Critical realism and associated methodologies have many objectors, as they challenge well established philosophical paradigms. Bearing in mind that some confuse critical realism with naive realism, it does not always get a proper hearing, while others are misdirected for nonfamiliarity with the whole body of writings. For example, Kemp (2005) suggests that social science should take a cue from evolutionary biology rather than physics or chemistry, whereas Bhaskar's (1986) discussion of the TMSA posits evolutionary biology as an analogy for social change.

The main objections to critical naturalism centre on the ontological status of social entities and causality. Cruickshank (2004) turns one of its favorite tools, the immanent critique on critical realism itself with the conclusion that there is slippage between two ontologies, one on the transitive and the other on the intransitive dimension as it pursues its "hegemonic project" to “conceptually re-tool the natural and social sciences" (Cruickshank 2004, 567). The critique does not call for the dropping of critical realism; instead, it is an invitation to dialogue on the status of social ontology. Both Nash (1999) and Varela (2002) call for a modest form of realism in view of the problematic social ontology.

Against ontology, following Wittgenstein's approach to language in philosophy, Kivinen and Piiroinen $(2004,238)$ argue that "...ontology is a language game played by a certain breed of philosophers, most of whom call themselves realists....", and that it has no bearing on social science. Realists are accused of searching for 'truth', or things in themselves. Kivinen and Piiroinen (2004) see critical realism as the futile pursuit of the one correct description of everything, which must itself lie outside the set of all possible descriptions. However, as earlier explained, critical realism accepts epistemological relativism: what is sought is always a fallible account of reality. A similar argument by Fay (1990) is discussed in Cruickshank (2002).

Within information systems research, the critical value of Monod (2004) and Klein's (2004) responses to the proposal of Mingers (2004b) for critical realism as underpinning philosophy for 
information systems research was again limited by their lack of familiarity with realist literature (Mingers 2004a). While Monod (2004) vigorously defends Kantian idealism against critical realism's challenge, Klein (2004) finds it a better synthesis of the post-positivist tradition because it includes aspects of hermeneutics but with an outdated socio-theoretic base. He agrees with Cruickshank (2004) on the need to clarify the dual ontology. ${ }^{6}$

Critical realism's ontological perspective raises significant philosophical issues for social science, and this may also lead to misunderstandings. Dean, Joseph, and Norrie's (2005) introduction to critical realism outlines four areas that raise significant questions to social science research relevant to the objections cited above. These are first, critical realism's 'underlabourer' status, i.e. that critical realism may at times appear as a philosophy for science (role as underlabourer), but also as a social theory in its own right; second, there is the relationship between dialectical critical realism (DCR) and critical and poststructural theory; third, there is the question of DCR's account of freedom and universality; fourth, there is the issue of the relationship between critical realism and meta-reality (the spiritual turn). These are issues that invite contribution and debate from researchers, especially in the social sciences, and ought to be given due consideration when using critical realist methodologies in research.

\section{Philosophy and scholarship in Africa}

Hountondji $(2002,125)$ defines African philosophy as "a set of texts, specifically the set of texts written by Africans and described as philosophical by the Authors themselves". Ever since Placide Tempels suggested that there exists such a thing as African philosophy, much debate concerning Africa and its possibilities for philosophy has taken place. Various characterizations have been suggested, now recognized as ethno-philosophy, excavationist, professional, radical (Western postmodern critiques of ethnophilosophy), and "Nationalist-Ideological-Political" schools (Vest 2009; Wamba 2003) in the continuing interrogation of the idea of Africa, and of

\footnotetext{
${ }^{6}$ These issues were raised early in the debate. Bhaskar responds to some who acknowledge its worth but question issues such as the ontological status of social structures and usage of the intransitive dimension in the postscript to Bhaskar (1998).
} 
African philosophy. Attempts to break out of this unproductive cycle often have to first address the burden of unraveling the historical links between Africa and her former colonizers. The underlying unresolved issues of political and social justice rooted in histories of past domination continue to animate debate. At the same time, the mixing, melding, and reformulation of culture, raciality and the transition from traditional to modern societies has become irreversible, giving rise to what Mudimbe (2003) terms metis, a globalizing cosmopolitan mix of shades of humanity. According to Robins (2004), The latter perspective is especially favored by postcolonial scholars based in leading Western universities, with a bias towards postmodern theory such as the 'African Trinity' of Kwame Anthony Appiah, Achille Mbembe and Valentine Mudimbe.

Against these are African and cultural nationalists such as Zeleza (2004) and Murunga (2004), who decry postmodern cosmopolitanism's apparent disengagement with the lived reality of economic deprivation, war, and famine in Africa, structurally constrained by globalization pressures to open its markets under terms set by richer nations. This would imply that postmodern cosmopolitan African scholars could be complicit in sustaining their own economic and, more importantly, intellectual dependency.

Robins (2004) argues for a third way that calls for "a critical engagement with contemporary theory regardless of whether it is of 'western origin' or not” by African philosophers. Similarly, Vest (2009) revisits discourses in African philosophy and debates to term them "perverse and unnecessary dialogues" that have outlived their usefulness: they served as necessary dialogues in dealing with the material and phenomenal manifestations of colonialism, an avenue for a cathartic self-examination and cleansing in the early stages of African philosophy during the colonial and immediate postcolonial era.

Today, Africa together with other developing countries of the world is no longer considered a "basket case", but rather as the new frontier for investment opportunities by global capital. The West's moral authority to dictate economic and development policy was eroded by the failure of the Structural Adjustment Programs of the 1980s and early 1990s, and by the East Asian crisis of 1997. More recently, the global financial crisis hastened the pace of such re-evaluation by illustrating the fragility of the foundations of Western prosperity (Fine, Lapavitsas and Pincus 2001; Pooran 2010). Emerging global powers such as China, India and Brazil signal a new 
multipolar world with more complicated international relations, including new centers of intellectual production. Under these transitional conditions, African scholars have the opportunity to seize the moment and reformulate or come up with philosophies that meet Africa's contemporary needs. The summary above on the status of African scholarship indicates that its major themes have been captive to Western philosophy and modes of thinking, even when used in criticizing the West or as anti-colonial rhetoric.

A point of departure to new directions could be Prof Wamba dia Wamba's review of African philosophy and development (Wamba 2003, 5-6), which suggests seven urgent tasks for African philosophy:

1. The freeing of thought.

2. The production of principles to help conceptualize the universal emancipation of the African (singularly and collectively).

3. Helping to heal the African from the great disease of the incapacity to self-determine at all levels.

4. Theoretically orienting science and technology towards dealing with Africa-specific problems.

5. Theoretically freeing the politics of absolutely generic equality.

6. Inducing public debates on points of interest to public consciousness in Africa.

7. Contributing to the break-up of the triple refusal - to think for oneself, to take seriously one's entire history and to resist taking up the long term perspective.

According to Prof Wamba, these are conditions that must be fulfilled for African scholarship to be fully deployed. His discussion shows that they are all centered on freedom, emancipation, and a historically grounded self-awareness. These themes run through much of African philosophy and writing, and ought to be addressed for scholarship to be relevant and transformational: this is the main opportunity critical realism affords African scholarship. As has been outlined above, critical realism has an emancipatory intent through the identification of freedom-denying false beliefs (ideologies), which in turn provides a point of departure to take emancipatory action similar to the critical theory of the Frankfurt School. If we use the dialectical model, it takes the 
form of successive absenting of constraints to freedom. The main difference with critical social theory and similar approaches is that critical realism (as second moment critical naturalism) defines reality differently to provide a robust open ended analytical approach to the discovery of underlying causes. Such causes would include reasons and social norms, in addition to material realities, which greatly expand analytical scope especially in the area of development policy. Explanations could even be extended to dialectical forms in the understanding of complex socioeconomic phenomena, far beyond the positivist approaches currently dominant in development research and policy formulation.

\section{Critical realism in Africa's development research and policy}

In this section, three areas with significant potential for researchers shall be used to illustrate some opportunities for critical realism in Africa's development: undermining positivism's dominance in social science research and explanation, the need to take time and history into account, and the importance of thinking for oneself. Historically Africa has been the most marginalized continent politically, racially, and economically, and stands to benefit most from such an approach. Generally speaking, critical realism has not and may never become a mainstream movement in the West, for it serves the interests of the marginalized by taking on the establishment at a fundamental level (Norris 1999). Though this would appear as a weakness at first, it is the only possibility for a truly transformational critical (even revolutionary) endeavor. It has significant implications for the marginalized by giving them an opportunity to take on the establishment and challenge existing power relations.

An important hidden problem for development and social science research is positivism's dominance. According to Bhaskar (1986, 307-308), positivism is a dominant ideology that serves the interests of capitalist Western modernity through a reductionist approach even to complex social phenomena. This ensures that anything not in line with orthodoxy does not get a hearing, and is even demonized. It dominates academia and policy formulation despite the many and cogent critiques and recognizable development policy failures, especially visible in economics (Fine et. al. 2001). This argument is strengthened by the political response to the recent financial crisis to save banks and the existing financial system, without a fundamental rethinking of the use of statistical finance and mathematical (positive) economics that have been blamed as 
exacerbating the crisis (Financial Economists Roundtable 1999; McCloskey 2002; Taleb 2007). Alternatives such as heterodox economics which is associated with critical realism (Lawson 1997) and behavioral finance are yet to become more than marginal in university curricula.

It is not surprising therefore that academic and social science research in most parts of the world tends to follow the West in the preference for positivism's 'rigorous' deductive analysis using statistical methods. A major reason for this is that it is easier to publish such works as young scholars pursue tenure in the United States university system (Chen and Hirschheim 2004). Therefore it has little to do with efficacy of outputs, but rather an established academic system. African researchers trained in this tradition stand to benefit most from a critical realist approach, given the practical consequences of their policy advice. The assumptions underlying orthodox positivist analyses embody taken for-granted false beliefs that require explication for rejection as a step towards emancipation. When developing country scholars trained in orthodox methodologies at leading Western universities return home, they become brokers between international development policy bodies and their own governments. The concealed mismatch between methodology and reality manifests as poor project performance for which the blame is laid on the implementing government agency, rather than on the possibility of embedded inappropriate epistemological and ontological assumptions. A critical realist causal analysis of such failures would give an indication of underlying mechanisms that generate failure, and provide a starting point for querying any unexamined ideologies in operation through various discourses of development. For example, Morgan (2003) demonstrates how the World Bank and International Monetary Fund's (IMF) policies based on orthodox economics were a causal factor in the East Asian financial crisis of 1997.

Secondly, positivist explanations aim for generalizable and timeless explanations of social phenomena best exemplified by 'validated' formulas and models. This however would be an oversimplification of complex social realities and contexts, and ignores historical relations that continue to define the structure of international relations. A critical realist approach requires that such be factored into any analysis. For example, foreign aid should not be divorced from the reasons why in the first place such aid is necessary, and whose interests it serves. Wallerstein's (1991) historical and structural approach in his World System Theory attempts to do this. Path dependence, whereby events today are considered not independent of the past, is by now a well 
established concept in economics (Durlauf 2005). This would mean that the analysis of foreign aid and the role of donors cannot be divorced from historical relations of colonialism and global power disparities. Orthodox positive economics is incapable of doing this because its methodology does not allow time and history into equations other than as time series trends. A critical realist approach on the other hand will, without rejecting the positive aspects of rigorous mathematical analysis. This would expand the scope of development policy debate to include time and history in a robust manner.

Another way that time and history are marginalized in development discourse is when some African scholars, especially from the Diaspora, take on forms of postmodernism and poststructuralism that effectively ignores material reality. Their internationally reputed works in Western academia are perceived as irrelevant to a continent with serious social and material problems, yet it is a vibrant and enduring one for those living there. An illustrative case is Vambe and Zegeye's (2007) critique of some works by prominent scholars of Africa, namely, Kwame Anthony Appiah and Achille Mbembe. They argue that these works are founded on the two writers' insufficient grasp of historical issues, and thus downplay agency by Africans. They feel it "necessary to undermine attempts at canonizing theoretical texts such as those produced by these two influential scholars"; as they state in the case of Appiah, "Though a man of letters mostly validated by the West, Appiah is out of touch with the realities of Africa." (Vambe and Zegeye 2007, 11). An approach that is more analytically incisive but also completely in touch with history would therefore be a great improvement for socio-economic analysis in Africa.

Our last point is on the importance of thinking for oneself. From the point of view of development research and policy, this relates to the appropriateness of policy projects that are conceived elsewhere for Africa. International development agencies such as the World Bank and the IMF regularly issue policy guidance on how best to 'develop'. These have varied over the years from modernization, import substitution, industrialization, structural adjustment, poverty fighting, and the comprehensive development framework today (Emmerij 2005). Evidence from countries that have developed in Asia however shows that development is complex and context dependent. Another well known case is where the West dominates the World Trade Organization and recommends free trade for Africa to develop by opening up its markets, while simultaneously defending market distorting agricultural subsidies to protect its farmers. Many 
development projects fail because they are conceived out of context, or are outrightly misguided. For any meaningful development to happen, it is important that African policy makers attain a level of self-awareness and confidence to come up with what works, rather than implementing what some other 'expert' says will work. This would almost certainly include a process of emancipation from ideologies and thought patterns that keep African policy makers in a state of subjection to foreign experts. Such a process would have to be at the individual and social and societal levels. Critical realism provides some tools and concepts to initiate this process, but more importantly, knowledge developed from critical realist research would institutionalize the change as it is taught in schools and universities.

The three cases cited above are merely indicative of a broad array of possibilities for extending current scholarship. Critical realism is both a philosophy and an implicit social theory, because one cannot divorce abstract thought from practice. It integrates previous concepts from positivism, critical theory and interpretivism into a single coherent philosophical system. By giving pre-eminence to ontology rather than epistemology, critical realism raises important questions for both thought and practice in Africa.

\section{Conclusion}

This paper explains the basic concepts of critical realism for an African audience, especially philosophers and social scientists concerned with social and economic development. It is premised on the idea that critical realism is sufficiently critical of the Western modernity that developing countries are eagerly pursuing despite its being evidently founded on a narrow materialist positivist intellectual base. Recent experiences from a series of global financial crises and development policy failures in Africa (structural adjustment), Asia (East Asian financial crisis), North America and Europe (global financial crisis) indicate that this base is indeed narrow.

Today's world is a rapidly changing one. The information age, the mobile telephone revolution in poor countries, global warming, successful popular revolutions, growing middle-class prosperity amidst rising inequality, and a shift in the balance of power from the West/North to the East/South all call for new ways to construct knowledge. Critical realism is not a simple 
philosophical system, and may put one at loggerheads with the establishment. However, its richer analytical framework binds many previous threads of social and philosophical analysis to go beyond the material to the ethical dimensions of humanity. Human values take center stage with freedom at the fore: any constraint to its attainment becomes a legitimate subjects/object for analysis and possible emancipatory action. It is relatively young, beginning less than forty years ago, to ten years ago for its latest form. Empirical critical realist research studies are not many even in Europe where it began, partly because it is still developing methodologically, but also due to the heavy investment required to master it adequately for research purposes. This is likely to be a continuing challenge to its uptake.

It has been argued that the search for dialogues beyond the perverse to the necessary (Vest 2009) in debate by African philosophers and researchers, and their efforts to 'break the triple refusal' as Prof. Wamba $(2003,6)$ suggests, would be reenergized by critical realism. It is a philosophy that purports to overturn Kant and Hegel, effectively the whole of European philosophy. Not surprisingly, its later forms have been identified with the postcolonial movement, and with the end of Western cultural dominance (Patomäki 2002). This presents both an opportunity and a challenge for African philosophy. In development policy and research, it could lead to new forms of knowledge that undermine positivism's dominance, that take time and history into account, and that generate conditions under which Africa's policy makers could cultivate the 'capacity to think for themselves'. Such have been found to be important precedents for any meaningful development to happen in Africa.

\section{References}

Ackroyd, S, and S. Fleetwood. 2000. Realist Perspectives on Management and Organisations. London: Routledge.

Archer, M.S. 1995. Realist social theory : the morphogenetic approach. Cambridge: Cambridge University Press.

Bhaskar, R. 1978. A realist theory of science. Hassocks, Sussex: Harvester Press.

--. 1986. Scientific realism and human emancipation. London: Verso.

--. 1993. Dialectic: The Pulse of Freedom. London: Verso. 
--. 1998. The possibility of naturalism: a philosophical critique of the contemporary human sciences, 3rd Edition. London: Routledge.

--. 2000. From east to west: the odyssey of a soul. London: Routledge.

Boyd, R. 2002. "Scientific Realism". Zalta, E.N. ed. The Stanford Encyclopedia of Philosophy. http://plato.stanford.edu/archives/sum2002/entries/scientific-realism

Chen, W., and R. Hirschheim. 2004. “A Paradigmatic and Methodological Examination of Information Systems Research from 1991 to 2001”. Information Systems Journal, 14, pp.197-235.

Clark, S. 1990. “Annales Historians”. Skinner, Q. ed. The return of grand theory in the human sciences. Cambridge: Cambridge University Press, pp.177- 198.

Collier, A. 1994. Critical realism : an introduction to Roy Bhaskar's philosophy. London: Verso.

Cruickshank, J. 2002. "Critical realism and critical philosophy: On the Usefulness of philosophical problems". Journal of Critical Realism, Vol.1 No.1, pp.49-66.

--. 2004. "A tale of two ontologies: an immanent critique of critical realism". The Sociological Review, Vol.52 No.4, pp.567-585.

Dean, K., J. Joseph and A. Norrie. 2005. "Editorial: New Essays in Critical Realism”. New formations, 56, Autum, pp.7-20.

Durlauf, S.N. 2005. “Complexity and Empirical Economics”. Economic Journal, Vol. 115 No. 504, pp. F225-F243.

Emmerij, L. 2005. "Turning points in development thinking and practice". Paper presented at the WIDER Jubilee Conference on WIDER Thinking Ahead: The Future of Development Economics, Helsinki

Fay, B. 1990. “Critical realism?” Journal for the Theory of Social Behavior, Vol.20 No.1, pp.33-41.

Financial Economists Roundtable. 1999. "Statement on Long-term Capital Management and the Report of the President's Working Group on Financial Markets". The Financier, Vol.6 Nos.2 and 3, pp.6-9.

Fine, B., C. Lapavitsas and J. Pincus eds. 2001. Development policy in the twenty-first century : beyond the post-Washington consensus. London: Routledge.

Giddens, A. 1979. Central problems in social theory : action, structure and contradiction in social analysis. London: Macmillan.

Hountondji, P. 2002. “An Alienated Literature”. Coetzee, P.H. and A.P.J. Roux eds. Philosophy from Africa: a text with readings, 2nd Edition. Cape Town: Oxford University Press, pp.125-136.

Kemp, S. 2005. “Critical Realism and the Limits of Philosophy”. European Journal of Social Theory, Vol.8 No.2, pp.171-191. 
Kivinen, O. and T. Piiroinen. 2004. "The Relevance of Ontological Commitments in Social Sciences: Realist and Pragmatist Viewpoints". Journal for the Theory of Social Behavior, Vol.34 No.3, pp.231-248.

Klein, H.K. 2004. "Seeking the New and the Critical in Critical Realism: de'ja' vu?" Information and Organization, 14, pp.123-144.

Lawson, T. 1997. Economics and reality. New York: Routledge.

McCloskey, D. 2002. The Secret Sins of Economics. Chicago: Prickly Paradigm Press.

Mingers, J. 2004a. "Critical realism and information systems: brief responses to Monod and Klein". Information and Organization, 14, pp.145-153.

--. 2004b. "Real-izing Information Systems: Critical Realism as an Underpinning Philosophy for Information Systems". Information and Organization, 14, pp.87-103.

Monod, E. 2004. "Einstein, Heisenberg, Kant: Methodological Distinction and Conditions of Possibilities". Information and Organization, 14, pp.105-121.

Morgan, J. 2003. "The Global Power of Orthodox Economics". Journal of Critical Realism, Vol.1 No.2, pp.7-34.

Mudimbe, V.Y. 2003. "Globalization and African Identity”. The New Centennial Review, Vol.3 No.2, pp.205-218.

Murunga, G.R. 2004. “African Cultural Identity and Self-Writing”. Africa Review of Books (October), pp.15-16.

Mutch, A. 2002. "Actors and Networks or Agents and Structures: Towards a Realist View of Information Systems". Organization, Vol.9 No.3, pp.477-496.

Nash, R. 1999. "What is Real and What is Realism in Sociology?" Journal for the Theory of Social Behavior, Vol.29 No.4, pp.445-466.

Norris, C. 1999. "Roy Bhaskar Interviewed". The Philosophers' Magazine, 8. http://www.raggedclaws.com/criticalrealism/archive/rbhaskar_rbi.html Access date 13/17/2007

Patomäki, H. 2002. "From East to West: Emergent Global Philosophies - Beginnings of the End of Western Dominance?" Theory, Culture and Society, Vol.19 No.3, pp.89-111.

Pedro, G.M. 2009. "A brief intellectual history of Early Realism in IR: a Critical Realism? Niebuhr, Morgenthau, Phenomenology and Critical Realism". Paper presented at the International Association of Critical Realism, Rio de Janeiro.

Pooran, P.N. 2010. "Global Financial Crisis: A mid-year review of progress to date”. World Economics, Vol.11 No.3, pp.127-132.

Porpora, D.V. 2005. “The Spiritual Turn in Critical Realism”. New formations, Vol.56, Autum, pp.147161. 
Quine, W.V.O. 1951. "Two Dogmas of Empiricism”. The Philosophical Review, 60, pp.20-43. http://www.ditext.com/quine/quine.html

Robins, S. 2004. “The (Third) World is a Ghetto'? Looking for a Third Space between 'Postmodern' Cosmopolitanism and Cultural Nationalism”. CODESRIA Bulletin, 1 and 2, pp.18 - 26.

Ruccio, D.F., and L.H. Simon. 1992. "Perspectives on Underdevelopment". Jameson, K.P. and C.K. Wilber eds. The Political Economy of Development and Underdevelopment, 5th edition. New York: McGraw Hill, pp.119-150.

Schumacher, E.F. 1974. Small is Beautiful : A Study of Economics as if People Mattered. London: Sphere Books.

Schurz, G. 2001. "What Is 'Normal'? An Evolution-Theoretic Foundation for Normic Laws and Their Relation to Statistical Normality". Philosophy of Science, Vol.68 No.4, pp.476-497.

Taleb, N.N. 2007. Fooled by Randomness: The Hidden Role of Chance in Life and in the Markets, 2nd Edition. London: Penguin.

Vambe, M.T., and A. Zegeye. 2007. "Notes on theorizing black diaspora from Africa". African Identities, Vol.5 No.1, pp.5-32.

Varela, C.R. 2002. "The Impossibility of Which Naturalism? A Response and a Reply". Journal for the Theory of Social Behaviour, Vol.32 No.1, pp.105-111.

Vest, J.L. 2009. "Perverse and Necessary Dialogues in African Philosophy". Thought and Practice: A Journal of the Philosophical Association of Kenya, New Series, Vol.1 No.2, pp.1-23.

Wallerstein, I.M. 1991. Unthinking social science : the limits of nineteenth-century paradigms. Cambridge: Polity Press.

Wamba, E.W. d. 2003. "On the state of african philosophy and development". Journal of African Philosophy, Vol2, http://www.africanphilosophy.com/issue2/diawamba.html

Zeleza, P.T. 2004. "Africanity: The Author Refers to the $\backslash$ Mbembe/Zeleza Debatel". CODESRIA Bulletin Nos. 1 and 2, 26-27. 